\title{
Impact of primary food allergies on the introduction of other foods amongst Canadian children
}

\author{
Mary McHenry ${ }^{1 *}$, Wade Watson ${ }^{1,2}$ \\ From Canadian Society of Allergy and Clinical Immunology Annual Scientific Meeting 2012 \\ Calgary, Canada. 11-14 October 2012
}

\section{Background}

Food-allergic children frequently avoid other foods. We hypothesized that parents of food-allergic children are not given consistent advice regarding introduction of allergenic foods; that these foods are avoided or delayed; and that there is significant anxiety when introducing new foods.

\section{Methods}

An online survey was administered via Anaphylaxis Canada's website to Canadian parents and caregivers who are registered members of this organization and who have a child with a food allergy.

\section{Results}

644 parents completed the online survey (60\% male children, average age at diagnosis 21.8 months). The most common allergies were peanut (49\%), milk (23\%), and egg (18\%). $51 \%$ of families were given advice regarding the introduction of other allergenic foods, $97 \%$ followed through with this advice. $72 \%$ were told to avoid certain foods, $41 \%$ to delay certain foods, and $14 \%$ were given varied advice. $58 \%$ of parents avoided or delayed other highly allergenic foods, mainly due to a fear of allergic reaction or anaphylaxis (93\%). 69\% of children did not have an allergic reaction when these foods were introduced. $68 \%$ of parents felt moderate or high levels of anxiety when introducing other foods.

\footnotetext{
* Correspondence: jamiesonmary@gmail.com

'Department of Pediatrics, Faculty of Medicine, Dalhousie University, Halifax NS, Canada

Full list of author information is available at the end of the article
}

\section{Conclusions}

Families of children with food allergies receive varied advice regarding the introduction of new foods. The majority of children did not have an allergic reaction to the new food, even if it was initially avoided or delayed. Most parents feel moderate to high levels of anxiety when introducing new foods to their children. A more consistent approach to this advice may decrease parental anxiety.

\section{Author details}

'Department of Pediatrics, Faculty of Medicine, Dalhousie University, Halifax NS, Canada. ${ }^{2}$ Division of Allergy, IWK Health Centre, Halifax NS, Canada.

Published: 2 November 2012

doi:10.1186/1710-1492-8-S1-A10

Cite this article as: McHenry and Watson: Impact of primary food allergies on the introduction of other foods amongst Canadian children. Allergy, Asthma \& Clinical Immunology 2012 8(Suppl 1):A10.

Submit your next manuscript to BioMed Central and take full advantage of:

- Convenient online submission

- Thorough peer review

- No space constraints or color figure charges

- Immediate publication on acceptance

- Inclusion in PubMed, CAS, Scopus and Google Scholar

- Research which is freely available for redistribution

Submit your manuscript at www.biomedcentral.com/submit

\section{() Biomed Central}

C Biomed Central

() 2012 McHenry and Watson; licensee BioMed Central Ltd. This is an Open Access article distributed under the terms of the Creative Commons Attribution License (http://creativecommons.org/licenses/by/2.0), which permits unrestricted use, distribution, and reproduction in any medium, provided the original work is properly cited. 